\title{
Protoplast isolation and culture for banana regeneration via somatic embryogenesis
}

\author{
Robert HAÏCOUR ${ }^{1 *}$, Akym AsSANI ${ }^{2}$, Viet BUI TRANG ${ }^{3}$, Abdelkarim GUEDIRA ${ }^{4}$ \\ ${ }^{1}$ Lab. Ecol. Syst. Evol., \\ UMR 8079, Bât 362, \\ Protoplast isolation and culture for banana regeneration via somatic \\ embryogenesis.
}

Univ. Paris Sud XI,

F- 91405 Orsay Cedex, France

robert.haicour@u-psud.fr

2 Univ. Guelph, Dep. Plant Agric., Bovey Building, N1G 2W1, Guelph,

Ontario, Canada

${ }^{3}$ Lab. Physiol. Vég.,

227 Nguyen Van Cu, Q.5,

Hô Chi Minh Ville, Viet Nam

${ }^{4}$ Dép. Biol., Lab. Physiol. Vég., Fac. Sci. Rabat,

Univ. Mohammed V Agdal,

Ave. Ibn Battouta, BP 1014,

1000 Rabat, Maroc
Abstract - Introduction. This protocol describes a method for obtaining protoplasts from banana leaves, calli and cell suspensions, and their sustainable development via somatic embryogenesis from embryogenic cell suspensions. The principle, key advantages, starting plant material, time required and expected results are presented. Materials and methods. This part describes the required laboratory materials, and media preparation for protoplast production and culture. Results. The first protoplasts may be seen after $30 \mathrm{~min}$ of incubation in enzyme maceration. With protoplasts from embryogenic cell suspension, complete development into a whole plant, through somatic embryogenesis, is observed in 12 weeks. The first cell divisions occur on feeder layers 3-8 days after protoplast plating. Proembryo formation is observed 14-21 days after initiation of protoplast culture. The transfer of derived embryo plantlets, at 8-10 weeks after protoplast plating, onto growth regulator-free medium, leads to plant rooting and elongation.

France / Musa sp. / method / culture media / culture techniques / protoplasts / somatic embryogenesis / in vitro regeneration
${ }^{*}$ Correspondence and reprints

Fruits, 2009, vol. 64, p. 261-269 (C) 2009 Cirad/EDP Sciences All rights reserved DOI: $10.1051 /$ fruits:2009021 www.fruits-journal.org Obtention et culture de protoplastes pour la régénération de bananiers par
embryogenèse somatique.

Résumé - Introduction. Le protocole décrit une méthode qui permet d'obtenir des protoplastes à partir de feuilles, de cals et de suspensions cellulaires de bananiers, ainsi que le développement, par embryogenèse somatique, des protoplastes issus de suspensions cellulaires embryogènes. Le principe, les principaux avantages de la méthode, le matériel végétal de départ, le temps nécessaire et les résultats attendus sont présentés. Matériel et méthodes. Cette partie décrit le matériel de laboratoire nécessaire, la préparation des milieux pour l'obtention de protoplastes, ainsi que leur culture. Résultats. Dès la première demi-heure d'incubation dans la solution enzymatique, les premiers protoplastes sont libérés. En 12 semaines, les protoplastes, issus de suspensions cellulaires embryogènes, se développent en plantes entières via l'embryogenèse somatique. Sur les couches nourricières, les protoplastes reconstituent leur paroi ; les premières divisions cellulaires s'observent (3 à 8) jours après l'étalement des protoplastes. La formation des proembryons se déroule entre (14 et 21) jours après le début des cultures de protoplastes. Puis, (8 à 10) semaines après l'étalement des protoplastes, leur évolution embryogène conduit à des plantules qui s'enracinent et s'allongent après transfert sur un milieu dépourvu de facteurs de croissance.

France / Musa sp. / méthode / milieu de culture / technique de culture / protoplaste / embryogenèse somatique / régénération in vitro 


\section{Introduction}

\section{Applications}

Banana protoplasts may be used for research purposes in physiology and phytopathology, and for banana breeding, including genetic transformation, through electroporation or PEG and somatic hybridisation [1-3].

\section{Principle}

Samples of embryogenic banana cell suspension, calli or in vitro leaves are digested with enzyme solution to remove the cell wall. After maceration, protoplasts are separated from debris by sieving [4].

Note: protoplasts are washed before control, with calcofluor white (brightener) [5], of the presence of the remaining wall, and control of their viability using fluoresceine diacetate (FDA) [6]. Protoplasts are then cultivated in appropriate conditions and form the cell wall, then undergo divisions leading to embryos, which develop into plantlets [7].

\section{Key advantages}

- Protoplasts provide a real single cell origin system.

- Such cells, when they are from banana cell suspension, may give rise to somatic embryos.

- A large number of protoplasts can be obtained $\left[10^{7}\right.$ to $\left.\left(3 \times 10^{7}\right)\right]$ from $1 \mathrm{~mL}$ of a packed-cell volume (PCV) cell suspension.

\section{Starting material $[8,9]$}

The protocol requires:

- an embryogenic banana cell suspension,

Note: better results are obtained using embryogenic cell suspension 3-4 days after the last subculture.

- banana calli,

- in vitro banana young leaves.

Note: in vitro plants freshly subcultured and transferred in dark conditions 2-3 weeks before use are used for protoplast isolation. Only very young leaves from in vitro plants, still yellow and rolled, are suitable for protoplasts allowing morphogenetic development.

\section{Time required}

Four to five hours are required for media preparation; $10-14 \mathrm{~h}$ for enzymatic treatment; $3 \mathrm{~h}$ for protoplast purification, staining and estimation of concentration; $1 \mathrm{~h}$ for plating; $2 \mathrm{~h}$ for feeder layer preparation; 2 months for embryo formation; 1214 weeks for the production of in vitro green rooted plants from protoplasts.

\section{Expected results}

Depending on the genotype and cell suspension quality, the protocol allows one to obtain:

- a variable protoplast yield: approx $\left[10^{7}\right.$ to $\left(3 \times 10^{7}\right)$ ] protoplasts per mL PCV cell suspension [9],

- protoplasts with size varying between (10 and 35) $\mu \mathrm{m}$,

- protoplasts with 70-90\% viability when just isolated,

- approximately $70-80 \%$ of wall reformation 6-8 days after protoplast isolation,

- approximately $0.2 \%$ of plated protoplasts producing embryos, 1.5-2.5 months after protoplast plating,

- plant regeneration from $45-65 \%$ of embryos, 3-4 months after protoplast plating.

\section{Materials and methods}

\subsection{Laboratory equipment}

The protocol requires:

- a culture room illuminated $12 \mathrm{~h}$ a day at $65 \mu \mathrm{mol} \cdot \mathrm{m}^{-2} \cdot \mathrm{s}^{-1}+\mathrm{a}$ dark compartment at $27-28^{\circ} \mathrm{C}$.

- sterile Petri dishes (6- and 10-cm diameter),

- sterile cones for Pipetman 5-10-mL pipettes,

- a centrifuge kept at $16-20{ }^{\circ} \mathrm{C}$, 
- sterile centrifugation tubes,

- sterile 500-200- $\mu \mathrm{m}$ sieve systems,

- a sterile $250-\mu \mathrm{m}$ metallic mesh,

- sterilised nitrocellulose filters (Black AA type Millipore),

- Millipore Millex GS filters,

- sterilised enzyme solutions,

- sterilised washing solutions,

- plastic film for Petri dish sealing,

- calcofluor white (fluorescent brightener):

$2 \mathrm{mg}$ in $200 \mu \mathrm{L}$ acetone or DMSO $+20 \mathrm{~mL}$ $\mathrm{H}_{2} \mathrm{O}+0.4 \mathrm{M} \mathrm{KCl}\left(30 \mathrm{~g} \cdot \mathrm{L}^{-1}\right)+45 \mathrm{mM} \mathrm{CaCl}_{2}$ $\left(5 \mathrm{~g} \cdot \mathrm{L}^{-1}\right)$,

- FDA solution at 0.01\%: FDA $2 \mathrm{mg}$ in $200 \mu \mathrm{L}$ acetone $+20 \mathrm{~mL} \mathrm{H}_{2} \mathrm{O}+0.4 \mathrm{M} \mathrm{KCl}$ $\left(30 \mathrm{~g} \cdot \mathrm{L}^{-1}\right)+45 \mathrm{mM} \mathrm{CaCl} 2\left(5 \mathrm{~g} \cdot \mathrm{L}^{-1}\right)$,

- a UV microscope,

- a hematocytometer,

- a N6 liquid culture medium for protoplasts,

- a PCM medium + sea-plaque agarose.

Note: all media have to be ready before protoplast isolation.

\subsection{Preparation of the enzymes and washing solutions}

\section{Enzyme solution EC1 for protoplast isolation from cell suspension}

- Add to distilled water: $1.5 \%$ cellulase RS (Yakult Honsha Co., Tokyo, Japan) + 0.15\% pectolyase Y 23 (Seishin Pharmaceutical Co., Tokyo, Japan $)+0.4 \mathrm{M} \mathrm{KCl}\left(30 \mathrm{~g} \cdot \mathrm{L}^{-1}\right)$ $+45 \mathrm{mM} \mathrm{CaCl}_{2}\left(5 \mathrm{~g} \cdot \mathrm{L}^{-1}\right)$.

- After $30 \mathrm{~min}$ of agitation, centrifuge the enzyme solution at $3000 \mathrm{rpm}$ for $1 \mathrm{~h}$; eliminate the pellet; then, filter the supernatant (pH 5.6) through a $0.22-\mu \mathrm{m}$ sterile Millipore filter.

\section{Enzyme solution EC2 for protoplast isolation from banana calli}

- Add to distilled water: $1.5 \%$ cellulase RS (Yakult Honsha Co., Tokyo, Japan) $+1 \%$ macerozyme (Sigma) $+0.15 \%$ pectolyase Y 23 (Seishin Pharmaceutical Co., Tokyo, Japan $)+204 \mathrm{mM} \mathrm{KCl}\left(\cong 15 \mathrm{~g} \cdot \mathrm{L}^{-1}\right)+67 \mathrm{mM}$
Table I.

Feed layer PCM medium required for banana protoplast and plant culture.

\begin{tabular}{|c|c|c|}
\hline Chemical elements & Formulae & $\begin{array}{c}\text { Doses } \\
\left(\mathrm{mg} \cdot \mathrm{mL}^{-1}\right)\end{array}$ \\
\hline \multicolumn{3}{|c|}{ Murashige and Skoog micro-element salts $(\times 2)$} \\
\hline Ammonium nitrate & $\mathrm{NH}_{4} \mathrm{NO}_{3}$ & 3300 \\
\hline Potassium nitrate & $\mathrm{KNO}_{3}$ & 3800 \\
\hline Calcium chloride & $\mathrm{CaCl}_{2}, 2 \mathrm{H}_{2} \mathrm{O}$ & 880 \\
\hline Magnesium sulphate & $\mathrm{MgSO}_{4}, 7 \mathrm{H}_{2} \mathrm{O}$ & 740 \\
\hline Potassium phosphate, monobasic & $\mathrm{KH}_{2} \mathrm{PO}_{4}$ & 340 \\
\hline \multicolumn{3}{|c|}{ Murashige and Skoog macro-element salts $(\times 2)$} \\
\hline Boric acid & $\mathrm{H}_{3} \mathrm{BO}_{3}$ & 12.4 \\
\hline Manganese sulphate & $\mathrm{MnSO}_{4}, 4 \mathrm{H}_{2} \mathrm{O}$ & 44.6 \\
\hline Zinc sulphate & $\mathrm{ZnSO}_{4}, 4 \mathrm{H}_{2} \mathrm{O}$ & 17.2 \\
\hline Potassium iodide & $\mathrm{KI}$ & 1.66 \\
\hline Molybdic acid (sodium salt) & $\mathrm{Na}_{2} \mathrm{MoO}_{4}, 2 \mathrm{H}_{2} \mathrm{O}$ & 0.5 \\
\hline Cupric sulphate & $\mathrm{CuSO}_{4}, 5 \mathrm{H}_{2} \mathrm{O}$ & 0.05 \\
\hline Cobalt chloride & $\mathrm{CoCL}_{2}, 6 \mathrm{H}_{2} \mathrm{O}$ & 0.05 \\
\hline \multicolumn{3}{|l|}{ Fe-EDTA } \\
\hline Ferrous sulphate & $\mathrm{FeSO}_{4}, 7 \mathrm{H}_{2} \mathrm{O}$ & 55.6 \\
\hline- & $\mathrm{Na}_{2}$-EDTA & 74.6 \\
\hline \multicolumn{3}{|l|}{$(\times 2)$ Morel and Wetmore vitamins } \\
\hline Meso-inositol & - & 200.0 \\
\hline Calcium panthotenate & - & 2.0 \\
\hline Nicotinic acid & - & 2.0 \\
\hline Pyridoxine chloridrate(B1) & - & 2.0 \\
\hline Thiamine & - & 2.0 \\
\hline Biotin & - & 0.02 \\
\hline \multicolumn{3}{|l|}{ Hormone } \\
\hline $2-4 D$ & - & 4 \\
\hline \multicolumn{3}{|l|}{ Additional elements } \\
\hline Glucose & - & 500 \\
\hline Maltose & - & $100 \times 10^{3}$ \\
\hline Saccharose & - & $40 \times 10^{3}$ \\
\hline Meso-inositol & - & 450 \\
\hline
\end{tabular}

$\mathrm{CaCl}_{2}\left(\cong 7.5 \mathrm{~g} \cdot \mathrm{L}^{-1}\right)$. Prepare, centrifuge and sterilise as for the enzyme solution EC1.

\section{Enzyme solution EC3 for protoplast isolation from in vitro banana leaves}

- Add to distilled water: 1\% cellulase RS (Yakult Honsha Co., Tokyo, Japan) + 1\% macerozyme (Sigma) $+0.15 \%$ pectolyase Y 23 (Seishin Pharmaceutical Co., Tokyo,

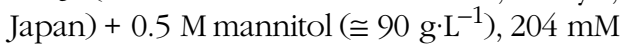


Table II.

N6 liquid culture medium required for banana protoplast culture.

\begin{tabular}{|c|c|c|}
\hline Chemical elements & Formulae & $\begin{array}{c}\text { Doses } \\
\left(\mathrm{mg} \cdot \mathrm{mL}^{-1}\right)\end{array}$ \\
\hline \multicolumn{3}{|l|}{ Macro-elements } \\
\hline Potassium nitrate & $\mathrm{KNO}_{3}$ & 2830 \\
\hline Ammonium sulphate & $\left(\mathrm{NH}_{4}\right)_{2} \mathrm{SO}_{4}$ & 463 \\
\hline Potassium phosphate, monobasic & $\mathrm{KH}_{2} \mathrm{PO}_{4}$ & 400 \\
\hline Calcium chloride & $\mathrm{CaCl}_{2}, 2 \mathrm{H}_{2} \mathrm{O}$ & 165 \\
\hline Magnesium sulphate & $\mathrm{MgSO}_{4}, 7 \mathrm{H}_{2} \mathrm{O}$ & 185 \\
\hline \multicolumn{3}{|l|}{ Micro-elements } \\
\hline Manganese sulphate & $\mathrm{MnSO}_{4}, \mathrm{H}_{2} \mathrm{O}$ & 4.4 \\
\hline Zinc sulphate & $\mathrm{ZnSO}_{4}, 7 \mathrm{H}_{2} \mathrm{O}$ & 1.3 \\
\hline Potassium iodide & $\mathrm{KI}$ & 0.8 \\
\hline Boric acid & $\mathrm{H}_{3} \mathrm{BO}_{4}$ & 1.6 \\
\hline \multicolumn{3}{|l|}{ Fe-EDTA } \\
\hline \multirow[t]{2}{*}{ Ferrous sulphate } & $\mathrm{FeSO}_{4}, 7 \mathrm{H}_{2} \mathrm{O}$ & 27.8 \\
\hline & $\mathrm{Na}_{2}$-EDTA & 37.3 \\
\hline \multicolumn{3}{|l|}{ Hydrosoluble components } \\
\hline \multicolumn{3}{|l|}{$\mathrm{KM}$ vitamins } \\
\hline Folic acid & - & 0.4 \\
\hline p-aminobenzoic & - & 0.02 \\
\hline Riboflavin & - & 0.2 \\
\hline Ascorbic acid & - & 1 \\
\hline Choline chloride & - & 1 \\
\hline B12 & - & 0.02 \\
\hline \multicolumn{3}{|l|}{ Sugars } \\
\hline Cellobiose & - & 250 \\
\hline Fructose & - & 250 \\
\hline Glucose & - & $70 \times 10^{3}$ \\
\hline Mannose & - & 250 \\
\hline Rhamnose & - & 250 \\
\hline Ribose & - & 250 \\
\hline Saccharose & - & 250 \\
\hline Sucrose & - & $40 \times 10^{3}$ \\
\hline Xylose & - & 250 \\
\hline \multicolumn{3}{|l|}{ Alcohols } \\
\hline Sorbitol & - & 250 \\
\hline Mannitol & - & 250 \\
\hline \multicolumn{3}{|l|}{ Organic acids } \\
\hline Na pyruvate & - & 5 \\
\hline Citric acid & - & 10 \\
\hline Malic acid & - & 10 \\
\hline Fumaric acid & - & 10 \\
\hline \multicolumn{3}{|l|}{ Liposoluble components } \\
\hline \multicolumn{3}{|l|}{ Vitamins } \\
\hline A & - & 0.01 \\
\hline D2 & - & 0.01 \\
\hline D3 & - & 0.01 \\
\hline \multicolumn{3}{|c|}{ Morel and Wetmore vitamins, normal concentration, (x1) } \\
\hline Calcium panthotenate & - & 1 \\
\hline Meso-inositol & - & 100 \\
\hline Nicotinic acid & - & 1 \\
\hline Pyridoxine chloridrate (B1) & - & 1 \\
\hline Thiamine & - & 1 \\
\hline Biotin & - & 0.01 \\
\hline
\end{tabular}

$\mathrm{KCl}\left(\cong 15 \mathrm{~g} \cdot \mathrm{L}^{-1}\right), 67 \mathrm{mM} \mathrm{CaCl}\left(\cong 7.5 \mathrm{~g} \cdot \mathrm{L}^{-1}\right)$. Prepare, centrifuge and sterilise as for the enzyme solution EC1.

\section{Washing solution (S1) for protoplasts from cell suspension}

Add to distilled water: $0.4 \mathrm{M} \mathrm{KCl}\left(30 \mathrm{~g} \cdot \mathrm{L}^{-1}\right)$ $+45 \mathrm{mM} \mathrm{CaCl}_{2}\left(5 \mathrm{~g} \cdot \mathrm{L}^{-1}\right)$. Adjust to $\mathrm{pH}$ 5.6. Autoclave for $20 \mathrm{~min}$ at $120{ }^{\circ} \mathrm{C}$.

\section{Washing solution (S2) for protoplasts from calli}

Add to distilled water: $204 \mathrm{mM} \mathrm{KCl}$ $\left(\cong 15 \mathrm{~g} \cdot \mathrm{L}^{-1}\right)+67 \mathrm{mM} \mathrm{CaCl}_{2}\left(\cong 7.5 \mathrm{~g} \cdot \mathrm{L}^{-1}\right)$. Adjust to $\mathrm{pH}$ 5.6. Autoclave for $20 \mathrm{~min}$ at $120^{\circ} \mathrm{C}$.

\section{Washing solution (S3) for protoplasts from leaves}

Add to distilled water: $204 \mathrm{mM} \mathrm{KCl}$ $\left(\cong 15 \mathrm{~g} \cdot \mathrm{L}^{-1}\right)+67 \mathrm{mM} \mathrm{CaCl} 2\left(\cong 7.5 \mathrm{~g} \cdot \mathrm{L}^{-1}\right)$ $+0.5 \mathrm{M}$ mannitol $\left(\cong 90 \mathrm{~g} \cdot \mathrm{L}^{-1}\right)$. Adjust to $\mathrm{pH}$ 5.6. Autoclave for $20 \mathrm{~min}$ at $120{ }^{\circ} \mathrm{C}$.

Note: for preliminary experiments (S2) washing solution is convenient for all types of banana protoplasts.

\subsection{Preparation of media for protoplast and plant culture}

\section{Feed layer media (PCM media)}

Prepare a $(\times 2)$-concentrated PCM medium (table I). Adjust it to $\mathrm{pH} 5.7$, then sterilise through a $0.22-\mu \mathrm{m}$ Millipore Millex GS filters (Millipore Corp.).

\section{N6 liquid culture media for protoplast culture}

Prepare a N6 liquid culture media [10] (table II). Adjust it to $\mathrm{pH} 5.7$, then sterilise by Millipore filtration.

\section{Protoplast regeneration medium}

Medium with [MS / 2] salts, Morel and Wetmore vitamins [11] at normal concentration $(\times 1)$, saccharose $\left(30 \mathrm{~g} \cdot \mathrm{L}^{-1}\right)$, indol-acetic acid $\left(0.4 \mathrm{mg} \cdot \mathrm{L}^{-1}\right)$, benzylaminopurine (0.5 $\left.\mathrm{mg} \cdot \mathrm{L}^{-1}\right)$, and agarose sea plaque $\left(7.5 \mathrm{~g} \cdot \mathrm{L}^{-1}\right)$ are required for protoplast regeneration. Adjust the medium to $\mathrm{pH} 5.7$, then sterilise by Millipore filtration. 


\section{Plant culture medium}

Prepare a regulator-free MS medium with $1.2 \mathrm{mM} \mathrm{NH} \mathrm{NO}_{3}\left(100 \mathrm{mg} \cdot \mathrm{L}^{-1}\right)$. Adjust the medium to $\mathrm{pH} 5.7$, then sterilise by autoclaving.

\section{Preparation of a nurse cell suspension medium}

- Sieve approximately $100 \mathrm{~mL}$ of banana cell suspension through a $250-\mu \mathrm{m}$ sterilised metallic mesh, in order to select only small cell aggregates. Wait until cells decant in this filtrate.

- When packed cell formation is achieved, eliminate half of the supernatant.

- Gently mix $6 \mathrm{~mL}$ banana packed cell volume into $100 \mathrm{~mL}(\times 2$-concentrated $) \mathrm{PCM}$ medium (figure 1A).

Note: for PCV cell manipulations, the point of the pipette or cone has to be cut to enlarge the section. The proportion of banana cells included in the feeder layer may be increased to $10 \%$.

\section{Preparation of feeder layer system [12]}

- Solubilise $1.2 \mathrm{~g}$ of agarose sea plaque (Sigma) in $100 \mathrm{~mL}$ double-distilled water ( $\mathrm{pH} 5.7$ ) (figure 1B).

- Autoclave for $30 \mathrm{~min}$ at $120^{\circ} \mathrm{C}$.

- When the temperature of the agarose solution $(100 \mathrm{~mL})$ has decreased to $35^{\circ} \mathrm{C}$, add PCM medium ( $\cong 100 \mathrm{~mL}$ ) containing feeder cells: it is the nurse cell suspension (figure 1C). Mix gently and immediately pour $10-12 \mathrm{~mL}$ of this mixture (final concentration: 3\% banana cells in $6 \mathrm{~g} \cdot \mathrm{L}^{-1}$ agarose gelified PCM medium) into small Petri dishes (6-cm diameter) (figure 1D). Cover with a sterilised nitrocellulose filter and seal with plastic film.

Note: feeder cultures may be keep at room temperature for 1-5 days before use.

\subsection{Protocol for protoplast isolation}

- Step 1. Protoplast isolation

Protoplast isolation from cell suspension:

- Use embryogenic suspension cultures 34 days after the last subculture, as donor material for the isolation of regenerating protoplasts.

\section{Table II.}

Continued.

\begin{tabular}{|c|c|c|}
\hline Chemical elements & Formulae & $\begin{array}{c}\text { Doses } \\
\left(\mathrm{mg} \cdot \mathrm{mL}^{-1}\right)\end{array}$ \\
\hline \multicolumn{3}{|l|}{ Hormones } \\
\hline $\begin{array}{l}2,4-D \\
(2-4 \text { dichloro-phenoxy-acetic acid })\end{array}$ & - & 0.2 \\
\hline NAA (naphthalene acetic acid) & - & 0.8 \\
\hline \multicolumn{3}{|l|}{ Additional elements } \\
\hline MES 2-(N-morpholino) ethanesulfonic acid & - & 100 \\
\hline Potassium phosphate, monobasic $\mathrm{KH}_{2} \mathrm{PO}_{4}$ & - & 250 \\
\hline Zeatine & - & 0.5 \\
\hline
\end{tabular}
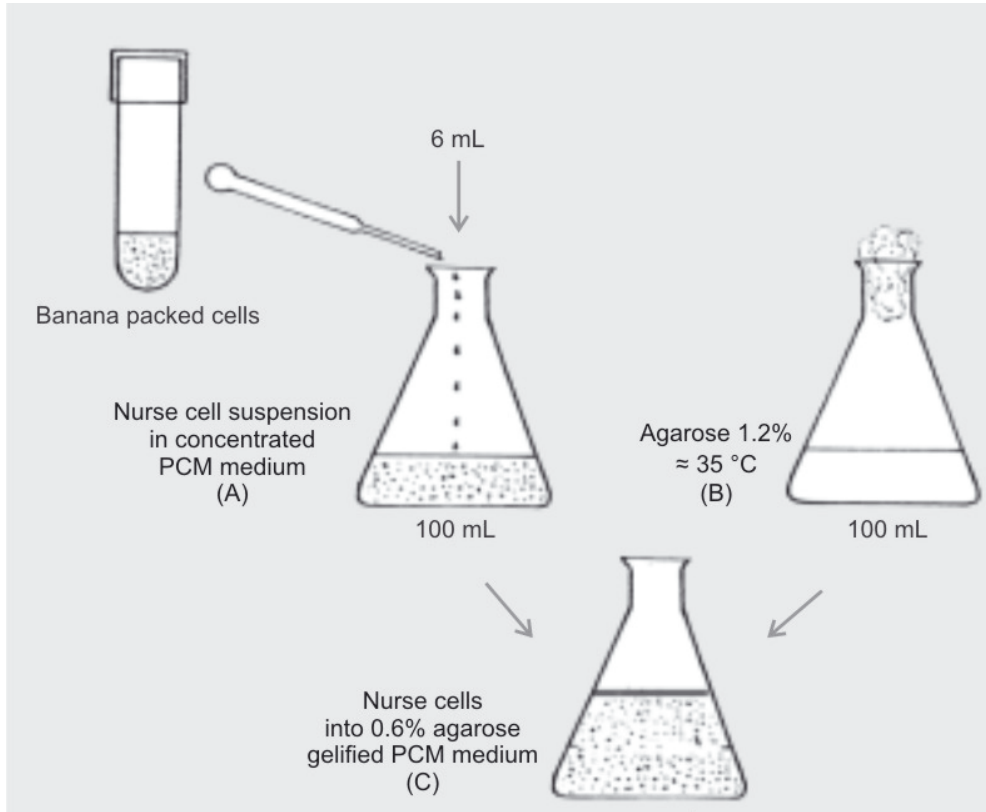
(C)

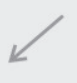

Nurse cells into $0.6 \%$ agarose gelified PCM medium

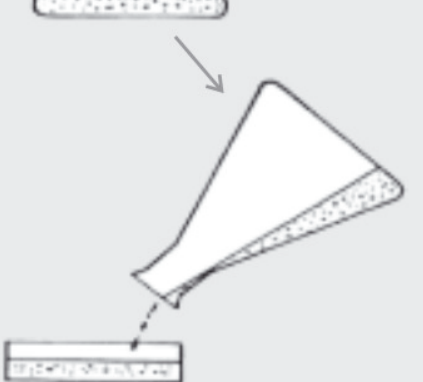

Gelified medium containing nurse cells into Petri dishes

(D)

- Sieve the cell suspensions through a sterile double $500-\mu \mathrm{m}$ and $200-\mu \mathrm{m}$ stainless mesh.

\section{Figure 1.}

Preparation of feeder layer media. 


\section{R. Haïcour et al.}

Figure 2.

Banana protoplast culture on feeder layer system.

Figure 3.

Freshly isolated banana protoplasts.
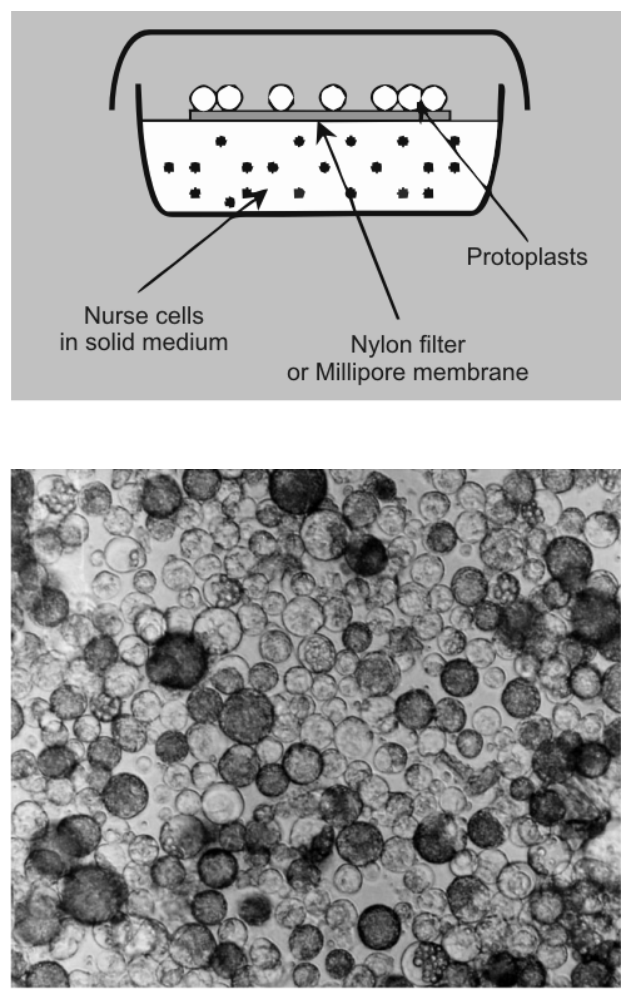

- Keep the filtrate, and use the packed cell volume for enzyme maceration.

Enzyme maceration:

- Put $2 \mathrm{~mL}$ of EC1 enzyme solution in a small Petri dish (5.5-cm diameter); add $1 \mathrm{~mL}$ of filtered packed cell suspensions.

- Mix gently.

- Incubate overnight (12-15 h) at $27^{\circ} \mathrm{C}$ in the dark, without shaking.

Note: the first protoplasts may be seen after $30 \mathrm{~min}$ of incubation.

Protoplast isolation from banana calli: - In a small Petri dish, add $4 \mathrm{~mL}$ of EC2 solution to $1 \mathrm{~g}$ (fresh material) of callus.

- Cut the callus into pieces (1-mm thickness) into EC2 solution.

- Incubate overnight (15-17 h) at $27^{\circ} \mathrm{C}$ in the dark, shake at 30 RPM.

Protoplast isolation from banana leaves:

- In a small Petri dish, weigh $1 \mathrm{~g}$ of very young leaves; add $4 \mathrm{~mL}$ of EC3 solution.

- Slice young leaves (1-mm thickness) into EC3 solution.
- Incubate overnight (13-15 h) at $27^{\circ} \mathrm{C}$ in the dark, shake at $30 \mathrm{rpm}$.

- Step 2. Protoplast purification

- Filter the digestion mixture through a [100$\mu \mathrm{m} / 25-\mu \mathrm{m}]$ metallic mesh combination to remove the debris and large cell colonies.

- When cell suspension is used as a source of protoplasts, rinse the mesh with S1 washing solution; rinse, respectively, with S2 and S3 washing solutions when calli or leaves are used as a source of protoplasts. Collect protoplasts in sterile tube(s), through centrifugation at $66 \mathrm{~g}$ for $5 \mathrm{~min}(650 \mathrm{rpm})$.

- The pellet has to be washed again two times (centrifugation at $66 \mathrm{~g}$ for $5 \mathrm{~min}$ ).

- Suspend the pellet in a fixed volume of N6 protoplast culture medium. After calcofluor staining, cell wall degradation can be visualised, through a UV microscope, on samples of protoplast suspension. Protoplast viability is determined using fluoresceine diacetate. Protoplast yield is estimated using a Nageotte hematocytometer.

- Dilute (or concentrate) protoplasts with N6 liquid culture medium for protoplasts to obtain a $10^{6}$ protoplasts $\cdot \mathrm{mL}^{-1}$ final concentration.

- Step 3. Protoplast cultivation

- Transfer $0.5 \mathrm{~mL}$ of protoplast suspension onto a nitrocellulose membrane in each Petri dish containing feeder layer culture (figure 2). Sealing with plastic film is highly recommended.

- Cultures are maintained in the dark at $27{ }^{\circ} \mathrm{C}$ for 21 days. Controls on cell wall reconstitution (calcofluor) and protoplast survey (fluoresceine diacetate), as well as mitotic activity of protoplast-derived cells, are done on samples of culture.

Notes: When taking samples of protoplasts for observations, cultures must be preserved to avoid risk of contamination.

The first cell divisions occur on feeder layers from 3-8 days after protoplast plating. Proembryo formation is observed 14-21 days after initiation of protoplast culture. Weekly addition to protoplasts of $0.3 \mathrm{~mL} \mathrm{N6}$ liquid culture medium for protoplasts is recommended. 
- Step 4. Protoplast regeneration through somatic embryogenesis

Three weeks after protoplast plating, proembryos are individually picked up from the feeder layer and gently transferred onto regeneration medium. Cultures are maintained at $27^{\circ} \mathrm{C}$ in the dark.

- Step 5. In vitro and soil plant development Eight to ten weeks after protoplast plating, transfer derived embryo plantlets onto growth regulator-free medium for rooting and elongation. Cultures are maintained at $27{ }^{\circ} \mathrm{C}$ under a $65 \mathrm{\mu mol} \cdot \mathrm{m}^{-2} \cdot \mathrm{s}^{-1}, 12$-h illumination a day photoperiod. After reaching the size of $10 \mathrm{~cm}$, plants may be transplanted into soil in a greenhouse for hardening.

\subsection{Troubleshooting}

Seven main problems can occur:

(a) Protoplast yield from cell suspension is low because the suspension quality is not good enough.

Solutions: regularly subculture cell suspension every 6 days before protoplast extraction, and plate samples of cell suspension on appropriate medium to verify it is still embryogenic.

(b) Low protoplast yield is obtained from calli or leaves: the tissues used as a source of protoplasts are probably too old.

Solutions: Use only the very young part of growing calli, and only 1-2-cm-long immature leaves.

(c) Protoplasts are not a spherical shape: cell wall digestion is incomplete.

Solutions: check with calcofluor under a UV microscope the eventual presence of the cell wall. Increase enzyme incubation duration $(+2-3 \mathrm{~h})$.

Use EC1' rather than EC1 or EC2 or EC3: $2 \%$ cellulase RS (Yakult Honsha Co., Tokyo, Japan) + 0.25\% pectolyase Y 23 (Seishin Pharmaceutical Co., Tokyo, Japan) + 0.5\% macerozyme (Sigma) $+0.2 \%$ hemicellulase $($ Sigma $)+204 \mathrm{mM} \mathrm{KCl}\left(15 \mathrm{~g} \cdot \mathrm{L}^{-1}\right)+67 \mathrm{mM}$ $\mathrm{CaCl}_{2}\left(7.5 \mathrm{~g} \cdot \mathrm{L}^{-1}\right)$.

(d) Protoplasts burst during enzymatic digestion: there was an error in osmoticum or digestion duration was too long.

Solutions: increase osmoticum or reduce digestion duration.
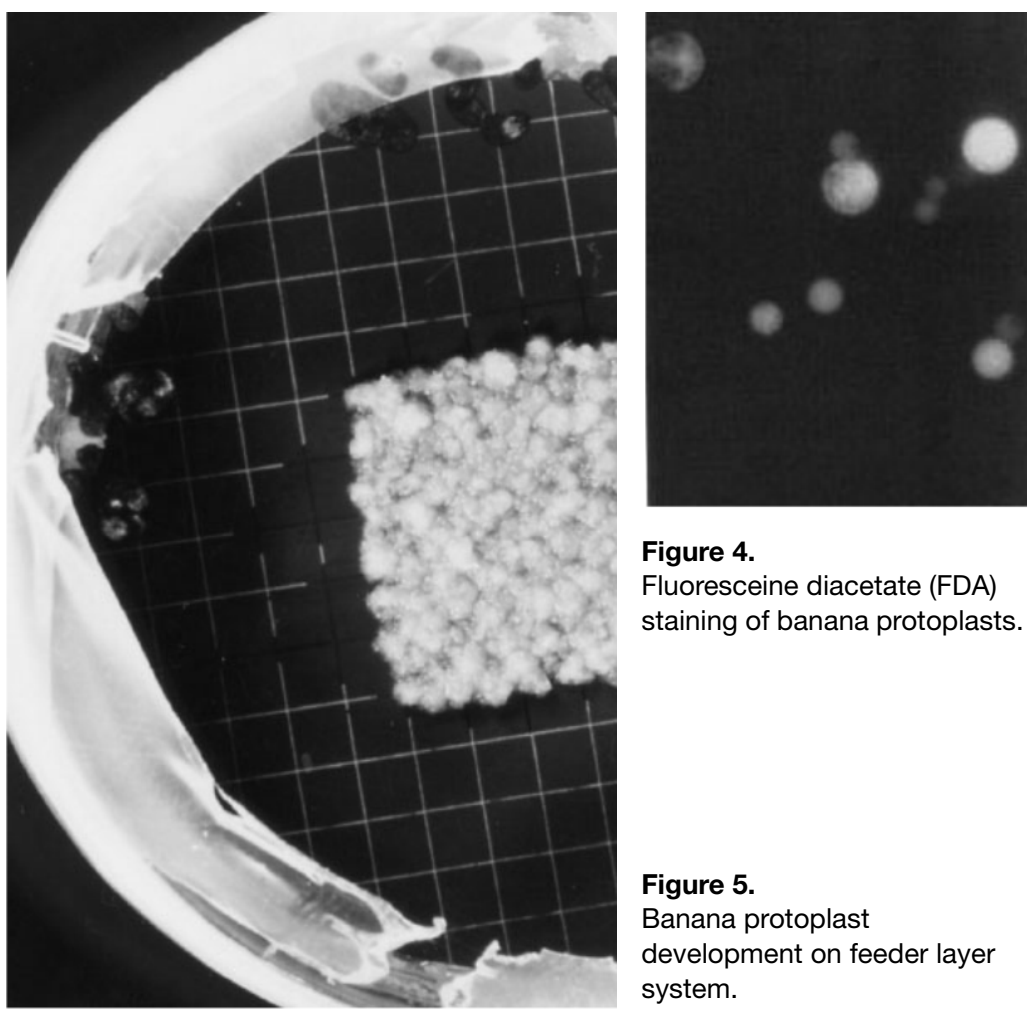

Figure 4.

Fluoresceine diacetate (FDA) staining of banana protoplasts.

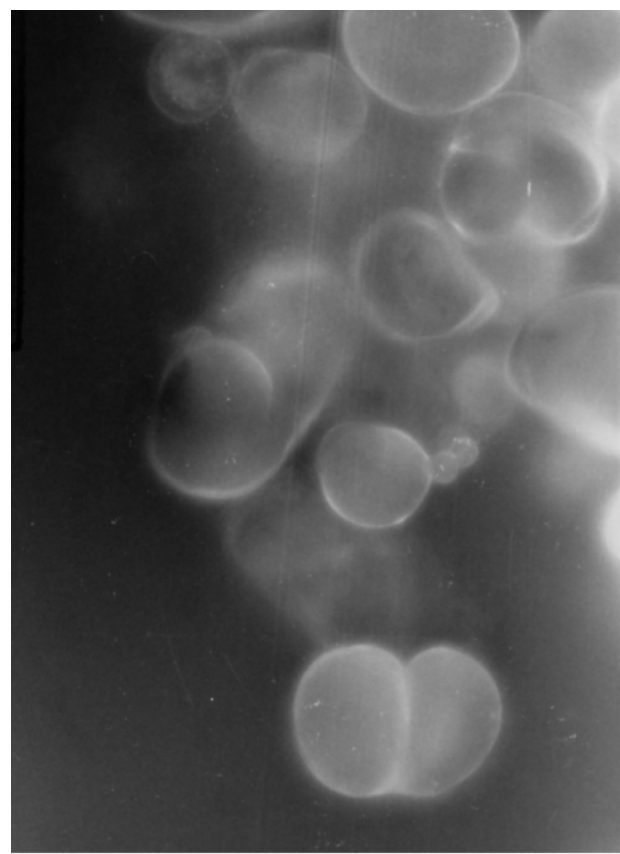

Figure 5.

Banana protoplast

development on feeder layer system.

Figure 6.

First division on banana protoplast culture (calcofluor staining).

(e) No protoplast development is observed on the feeder layer: the quality of the suspension or of protoplasts is not good enough. 


\section{R. Haïcour et al.}

Figure 7.

Banana embryo formation on feeder layer system.

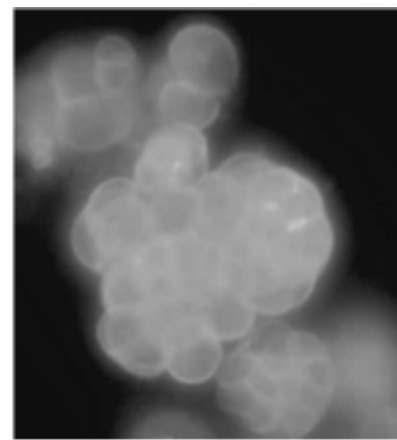

Figure 8.

Banana proembryo formation on feeder cell culture (calcofluor staining).

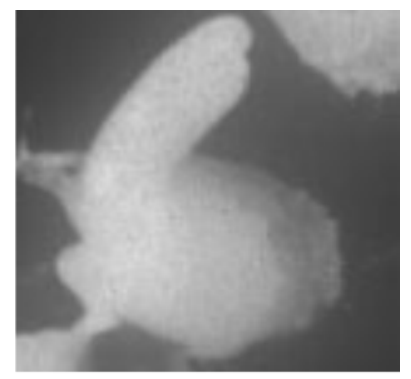

Figure 9.

Banana embryo germination on regeneration medium.

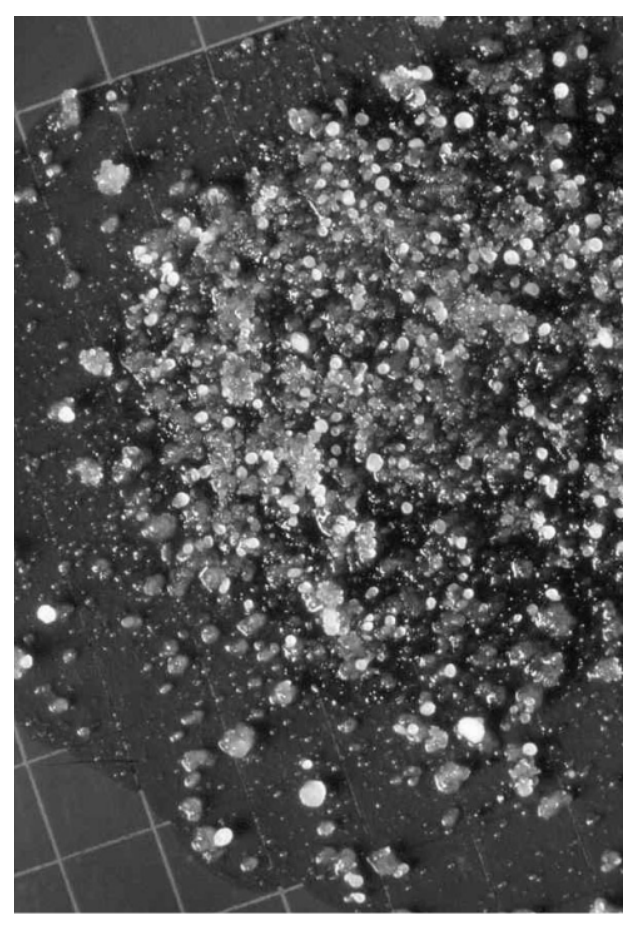

Solutions: check the embryogenic potential of cell suspension. If protoplasts brown, control the absence of debris in protoplast culture.

(f) Development of contaminants is observed in feeder cell medium: cell suspension is contaminated.

Solutions: use another cell suspension.

(g) Development of contaminants is observed among protoplasts on the nitrocellulose membrane: there was a failure in the sterilisation process.

Solutions: check the sterility of each medium, check tool sterilisation.

\section{Typical results obtained}

The first protoplasts may be seen after 30 min of incubation in enzyme maceration (figures 3, 4). With protoplasts from embryogenic cell suspension, complete development into a whole plant, through somatic embryogenesis, is observed in 12 weeks. The first cell divisions occur on feeder layers 3-8 days after protoplast plating [13] (figures 5, ๑). Proembryo formation is observed 14-21 days after initiation of protoplast culture (figures 7,8 ). The transfer of derived embryo plantlets, at 8-10 weeks after protoplast plating, onto growth regulator-free medium, leads to plant rooting (figure 9) and elongation.

\section{References}

[1] Sihachakr D., Protoplastes: isolement, culture, régénération et fusion au polyéthylène glycol, in: Haïcour R., Biotechnologies végétales, Lavoisier Tec et Doc, Techn. Lab., Paris, France, 2002, pp. 5-328.

[2] Matsumoto K., Vilarinhos A.D., Oka S., Somatic hybridization by electrofusion of banana protoplasts, Euphytica 125 (2002) 317-324.

[3] Assani A., Chabane D., Haïcour R., Bakry F., Wenzel G., Foroughi-Wehr B., Protoplast fusion in banana (Musa spp.): comparison of chemical (PEG: polyethylene glycol) and electrical procedure, Plant Cell Tissue Organ Cult. 83 (2005) 145-151.

[4] Assani A., Haïcour R., Bakry F., FouroughiWehr B., Les progrès réalisés dans la regénération des protoplastes de bananiers (Musa ssp.), in: Hamon S., Des modèles biologiques à l'amélioration des plantes, IRD Éd., Montpellier, France, 2001, pp. 193-206.

[5] Galbraith D.W., Microfluorometric quantitation of cellulose biosynthesis by plant protoplasts using calcofluor white, Physiol. Plant. 53 (1981) 111-116.

[6] Widholm J.M., The use of fluorescein diacetate and phenosaphranin for determining the viability of cultured cells, Stain Technol. 47 (1972) 189-194.

[7] Megia R., Haïcour R., Tizroutine S., Bui Trang V., Rossignol L., Sihachakr D., Schwendiman J., Plant regeneration from cultured protoplasts of the cooking banana cv. Bluggoe (Musa spp., ABB group), Plant Cell Rep. 13 (1993) 41-44.

[8] Bakry F., Choix du matériel à utiliser pour l'isolement de protoplastes de bananier (Musa sp.), Fruits 39 (7-8) (1984) 449-452.

[9] Assani A., Haïcour R., Wenzel G., FouroughiWehr B., Bakry F., Cote F., Ducreux G., Ambroise A., Grapin A., Influence of donor material and genotype on protoplast regeneration in banana and plantain cultivars 
(Musa spp.), Plant Sci. 162 (3) (2002) 355362.

[10] Kao K.N., Michayluk M.R., Nutritional requirements for growth of Vicia hajastana cells and protoplasts at a very low population density in liquid media, Planta 126 (1975) 105-110.

[11] Morel G., Wetmore R.H., Fern tissue culture, Am. J. Bot. 38 (1951) 141-143.

[12] Haïcour R., Assani A., Matsumoto K., Guedira A., Banana protoplasts, in: Mohan Jain S., Swennen R., Banana improvement:
Cellular, molecular biology, and induced mutations, Sci. Publ. Inc., Enfield, NH, USA, 2004, pp. 111-125

[13] Haïcour R., Rossignol L., Bui Trang V., Megia R., Tizroutine S., Maîtrise de la culture et de la regénération des protoplastes de bananier, en vue de la création de nouvelles structures génétiques, in: Dubois J., Demarly Y., Quel avenir pour l'amélioration des plantes ?, J. Libbey Eurotext (Éd.), Actual. Sci., Paris, France, 1994, pp. 211225. 